\title{
Salman Rushdie's Quichotte and the Post-truth Condition
}

\author{
Atri Majumder ${ }^{1} \&$ Gyanabati Khuraijam² \\ ${ }^{1}$ Research Scholar, Department of Management, Humanities and Social Sciences, National \\ Institute of Technology Agartala, E-mail: atri.cal@gmail.com,https://orcid.org/oooo-ooo3- \\ 2624-5703 \\ ${ }^{2}$ Assistant Professor, Department of Management, Humanities and Social Sciences, \\ National Institute of Technology Agartala, E-mail: khgyan79@yahoo.com
}

\begin{abstract}
The emergence of 'post-truth' has dramatically affected the contemporary socio-political discourses. The blurring of the distinctions between fact and fiction has become ostensible owing to the proliferation of social media and the pivotal role played by cyberspaces in creating volatile identities. The erosion of objectivity and the creation of a Baudrillardian 'hyperreality' have destabilized the position of truth irrevocably. The meteoric rise of far-right populist governments across the world with their jingoistic, xenophobic and parochial brand of politics, the erasure of subjective autonomy and invasion of privacy have pushed the world to the brink of moral anarchy, devoid of ethical values and veracity. Salman Rushdie's latest work Quichotte (2019) is a postmodern rendering of Miguel De Cervantes' picaresque novel Don Quixote. This paper attempts to critically analyse the novel vis-à-vis the 'post-truth condition'. The evolution of the concept of truth is traced through the ideas of various philosophers such as Michel Foucault, Alain Badiou, Jean Baudrillard and other philosophers in order to ascertain the origin and theoretical implications of 'post-truth'. Rushdie has foregrounded the contemporary socio-political issues like the impending catastrophic consequences of climate change, the prevalent opioid crisis and the precarious position of immigrants who are often victims of racist violence. He has characteristically employed magic realism and narrative pyrotechnics in the novel. The various intertextual references, allusions to popular culture, and autobiographical traces in Quichotteare also to be explored.
\end{abstract}

Keywords: post-truth, hyperreality, socio-political issues, magic realism, popular culture, intertextuality

“...the surreal, and even the absurd, now potentially offer the most accurate descriptors of real life" (Rushdie, 2019, p.222).

\section{Post-truth}

'Post-truth' has become an umbrella term for felicitously describing the tendencies and politics of contemporary times. 'Post-truth' was the Oxford English Dictionary's 2016 Word of the Year and is defined as "relating to or denoting circumstances in which people respond to feelings and beliefs than to facts." (Hornby, 2020, p.1202) It is worth noting that "the prefix 'post' is meant to indicate not so much the idea that we are 'past' truth in a temporal sense (as in 'post-war') but in the sense that truth has been eclipsed - thatit is irrelevant.” (Mcintyre, 2018, p.5) The term has gained momentum since its inception and has come to signify a gamut of rising phenomena globally. The

(c) AesthetixMS 2020. This Open Access article is published under a Creative Commons Attribution Non-Commercial 4.o International License (http://creativecommons.org/licenses/by-nc/4.o/), which permits non-commercial re-use, distribution, and reproduction in any medium, provided the original work is properly cited. For citation use the DOI. For commercial re-use, please contact editor@rupkatha.com. 
election of Donald Trump as the President of the United States of America, the Brexit fiasco, politically motivated disinformation campaigns in Hungary, Russia and Turkey have played pivotal roles in ushering the post-truth era. The dominance of social media and the concomitant proliferation of 'fake news' have restricted public discourse as "popularity now competes with logic and evidence as an arbiter of truth." (Hannan, 2018, p.7) The 'Cambridge Analytica' scandal shows that audiences are being micro-targeted to mould their beliefs and

"as such, post-truth is clearly part of the advent of the Experience Age, characterised by the dominance of emotional connection and the necessity of an instantaneous 'click' with content...one can easily noticethe increasing prevalence of a consumerist (i.e. utility-quasatisfaction maximising) audience behaviour." (Kalpokas, 2019, p.125)

The ostensible discordance between fact and fiction and the persistent erosion of truth, symptomatic of the post-truth condition, is attenuated by the serious problems of science denialism, cognitive bias and the burgeoning propagation of spurious facts.

\section{The Philosophical Concept of Truth}

The concept of truth has always been contested in the realm of philosophy and has accordingly evolved through the ages. Plato warned of false claims to knowledge and Socrates felt that though ignorance is remediable,

... the greater threat comes from those who have the hubris to think that they already know the truth, for then one might be impetuous enough to act on a falsehood.(Mcintyre, 2018, p.6)

The prominent conceptions of truth like correspondence, cohenterist, pragmatist, foundationalist and semantic, reflect the diversity of opinion regarding truth among philosophers. The most important aspect underlying these theories of truth is the idea of value-neutrality which rests on a rigid fact-value distinction. The "idea is that facts are ontologically objective in the sense above of being outside us, while values are entirely matters of our own inner subjectivity." (Richmond \& Porpora, 2019, p.6) However, in the post-truth era, this fact-value distinction has been obliterated, and following Nietzsche, truths have become"just fictions we have forgotten are fictions, a mobile army of metaphors on the move." (Caputo, 2016, p.124)

\section{Postmodernism and Post-truth}

The post-truth condition has been anticipated by poststructuralist and postmodernist thinkers like Michel Foucault, Alain Badiou and Jean Baudrillard. Kevin Kester asserts that "postmodernity is now the modernist post-truth...knowledge has been replaced with unsubstantiated opinion." (2018, p. 34)In the post-truth political culture, all truths have tended to become "mere opinions or expressions of ulterior private interests" and consequently,

"this devaluation of truth is held to undermine the democratic public sphere, paving the way for the rise of charlatanry, obscurantism and extremism. The descent of this disposition can be traced from a variety of events, from the innovations of information technology to the crises of the neoliberal hegemony." (Prozorov, 2018, p.18)

Foucault's analysis of truth as a political discourse which is ceaselessly contested and problematized, is characteristic of the post-truth culture where the free play of opinions and relativism have undermined truth. Foucault ascertains that "the problem is not changing people's 
consciousness...but the political, economic, institutional regime of the production of truth." (2000, p. 133)In delineating the function and nature of truth, Alain Badiou observes that "the ethic of truths, relation or un-relation, between the construction of a truth and its potency, is that by which we take the measure of what our times are capable of, as well as what our times are worth." (2014, p.55) Badiou notes "that the overwhelming majority of empirical instances of politics have nothing to do with truth. They organise a mixture of power and opinions." (2005, p. 97)Jean Baudrillard's concept of the 'simulacra' has effectively replaced the distinctions between truth and falsity, as images fail to bear any resemblance to reality whatsoever. The "postmodern world is caught up in television, advertising, copies of designer goods, cloning, the meaningless repetition of brand names and computer simulations of just about everything." (Colebrook, 2015, p.98) Reality has become increasingly virtualized as we have come to rely more and more on virtual memories and virtual interactions on the Internet. According to Baudrillard, "the virtual, in its various manifestations, has given us a completely new sense of reality", a 'hyperreality' which has no "correspondence to an actual world of representation." (Lundborg, 2016, pp.3-4) Baudrillard argues that

"Whereas we could face up to the unreality of the world as spectacle, we are defenceless before the extreme reality of this world, before this virtual perfection. We are, in fact, beyond all disalienation. This is the new form of terror, by comparison with which the horrors of alienation were very small." (1996, p.29)

\section{Fictional Spaces}

Though postmodernism can be considered as a precursor to the post-truth era, the roots of posttruth can be traced back to the dawn of civilisation as Yuval Noah Harari asserts,

"Humans have always lived in the age of post-truth. Homo sapiens is a post-truth species, whose power depends on creating and believing fictions. Ever since the Stone Age, selfreinforcing myths have served to unite human collectives...We are the only mammals that can cooperate with numerous strangers because only we can invent fictional stories, spread them around, and convince millions of others to believe in them." (2018, p. 33)

The intimate relation between truth and power has been revealed by this ability to spread fictions which distort as well as paradoxically create reality. David P. Levine observes that "fantasy has its own kind of truth" and this "fantasized power...entails mobilization of a considerable measure of against what Freud refers to as the reality principle, which is the principle that reality imposes limits on gratification." (2017, pp. 125-26)Jurgen Habermas relates "truthfulness to selfexpression...the capacity of art to create and articulate a view of the world." (Edgar, 2006, p. 163).

In 1943, George Orwell wrote: "What is peculiar to our own age is the abandonment of the idea that history could be truthfully written" and this holds true for our contemporary times as well. (2017, p.85). Fictional spaces renegotiate the objectivity of history to explore "alternative explanations" of the same 'truth' as "the events of the historian's plot are selected from a preexisting stock of facts, whereas the events of fictional narrative are invented by the author" (Simms, 2003, p.88). Jacques Ranciérecomments that "the clear division between reality and fiction makes a rational logic of history impossible as well as a science of history" (2004, p. 32). Tracy Bowell notes how fiction has "historically provided us with the means both to make sense of our experiences and to countenance possibilities other than the realities of our actual lives." (2018, p.170) 


\section{Quichotte}

Salman Rushdie has always engaged with contemporary politics and debates in his fiction, often in the form of caustic satire, and his latest work Quichotte is no exception. Quichotte is a postmodern rendering of Miguel de Cervantes' picaresque novel Don Quixote written in the $16^{\text {th }}$ century. The eponymous protagonist Quichotte is a travelling pharmaceutical salesman of Indian origin, working in America. His name is Ismail Smile, but he adopts the name Quichotte from the French opera Don Quichotte by Jules Massenet. He sets out on a chivalric quest to win the heart of a famous TV star, Miss Salma R, the femme fatale who is also of Indian origin like him. Quichotte brings his son Sancho into existence through his imagination, and together they travel across America. The characters of Miss Salma R and Sancho correspond to Don Quixote'sDulcinea and Sancho Panza. Rushdie introduces a metafictional story within the story in the form of Sam Duchamp (mostly referred to as 'Brother' in the novel), a spy thriller novelist, who is actually writing the story on Quichotte. The parallel life story of this author, who is also from Bombay like Quichotte, intersects with that of his fictive creation, as they both attempt to salvage the strained relationships with their sisters.

Besides the topical concerns of contemporary issues, Rushdie exposes the post-truth condition where the moorings of reality have been lost. In Imaginary Homelands, Rushdie stated that "Facts are hard to establish, and capable of being given many meanings. Reality is built on prejudices, misconceptions and ignorance as well as on our perceptiveness and knowledge." (2010, p.25) This seems to be an almost perfect diagnosis of the current post-truth situation which he terms as the "Age-of-Anything-Can Happen". Maggie Ann Bowers notes that "Rushdie's novels provide commentary on the dangers and pitfalls of contemporary cultural politics and attitudes." (2013, p.90) Rushdie presents an intricate tapestry of characters whose lives are interlaced with each other and who act as mouthpieces evoking the concerns and afflictions of the contemporary world. Rushdie also alludes to a vast array of characters and works of art drawn from both 'high' and 'low' culture. This postmodern pastiche makes heavy use of irony and sarcasm to critique the loss of depth to the mere surfaces, a predominant characteristic of contemporary culture as Sister laments:

"But now discontinuity ruled. Yesterday meant nothing and could not help you build tomorrow. Life had become a series of vanishing photographs, posted every day, gone the next. One had no story anymore. Character, narrative, history, were all dead. Only the flat caricature of the instant remained, and that was what one was judged by. To have lived long enough to witness the replacement of the depth of her chosen world's culture by its surfaces was a sad thing."(Rushdie, 2018, p.236)

\section{Popular Culture and Intertextuality}

Akin to Cervantes's Don Quixote who was a voracious reader of chivalric romances, Rushdie's Quichotte was obsessed with popular culture, especially reality television. He "fell victim to that increasingly prevalent psychological disorder in which the boundary between truth and lies became smudged and indistinct." (Rushdie, 2019, p.4) Consequently, he becomes completely alienated and mentally deranged as he later realises that:

"He distanced himself from old and new colleagues, new and old friends, and withdrew into himself, retreating so far, so deep, that nobody could follow him...he began to speak in TV references, and his grasp on reality loosened...The multiplicity, the everything of everything, the roar of narratives, the endless, transformation, the myth factory lost in the myth of itself: it unsettled him." (Rushdie, 2019, p.274) 
The novel abounds in intertextual references and allusions to popular culture ranging from Greek Drama, Crime and Punishment, Dante, Fahrenheit 451, classical science fiction novels to Looney Tune cartoons, Oprah Winfrey, Law \& Order, popular songs, Bollywood stars, cooking competition shows, and Jiminy Cricket. Rushdie's intention in deliberately including these references is elucidated by Brother's explanation to Sister:

"Destructive mind-numbing junk culture of his time just as Cervantes had gone to war with the junk culture of his own age...he wanted to incorporate elements of the parodic, and of satire and pastiche." (2019, p.289)

\section{Climate Change}

The complex plot of the novel takes an apocalyptic turn when a rupture appears in the cosmos, a tangential indicator of the imminent catastrophic consequences of climate change. The character in the novel, the billionaire scientist Evel Cent, who predicts this cataclysmic turn of events, is apparently based on the American entrepreneur and technologist Elon Musk. One of the most disruptive trends of the post truth era is the denial of science. In this post-truth age, science denialism has become a common phenomenon, as "evidence-based conclusions appear to be increasingly threatened by beliefs based on emotion and isolated personal experience. Global warming is perhaps the most egregious case of modern science denial." (Mcintyre, 2018, p.30) A 2013 survey of 4000 peer-reviewed papers found that "97 percent of scientists say that is very likely that human activity is causing global warming." (Dobson, 2016, p.92) However, in spite of the scientific consensus regarding anthropogenic climate change, the general public's beliefs on the matter vary widely:

"A 2015 Pew Research Center survey found that although 54\% of global respondents consider climate change a very serious problem, only $18 \%$ of Chinese and $45 \%$ of US residents agree with this view despite these two countries being the highest $\mathrm{CO}_{2}$ emitters worldwide. The same report indicates that in many economically advanced countries, including the US, UK, Canada, Germany and Australia, attitudes towards climate change are divided based on political ideologies." ("challenge of the post-truth era," 2018, p.1231)

In the novel, Evel Cent when confronted with the question of how serious and imminent the threats of environmental disaster are, replies that "the truth is the truth, and must be heard, however problematic it seems. I'm confident that when our science is judged everyone will accept our conclusions" (Rushdie, 2018, p.269). Quichotte also refers to other instances of irrational beliefs that are gaining popularity across the world:

"A man told him that in two years everyone would believe that the Earth was flat. A woman told him that vaccinations were part of a global conspiracy against children. A man told him that condensation trails left by high-flying jet aircraft were composed of chemical and biological agents that enable the psychological manipulation of human beings, or sterilised women to control the population explosion." (Rushdie, 2019, p.312)

\section{The Opioid Crisis}

The opioid crisis prevalent in America has been highlighted in Quichotte. The National Institute of Drug Abuse reports that

"Every day, more than 130 people in the United States die after overdosing on opioids. The misuse of and addiction to opioids-including prescription pain relievers, heroin, and 
synthetic opioids such as fentanyl-is a serious national crisis that affects public health as well as social and economic welfare." ("National Institute on Drug Abuse", 2019)

Miss Salma R, the New York television talk-show host and former Bollywood star, who has a bipolar diagnosis, falls prey to this opioid addiction and consequently undergoes a near-death experience when she overdoses. The drug she uses is produced by the pharmaceutical company owned by Dr. R.K. Smile, Quichotte's cousin. Dr. Smile illegally supplies the opioids to celebrities and he recalls John Kapoor who was jailed in the US for distributing opiates surreptitiously. (Raghavendra, 2019) This issue of drug addiction also bears personal significance to Rushdie as his "younger sister died from the consequences of addiction, and the book is centrally concerned with siblings trying to reconnect after separation." (Wickenden, n.d.)

\section{Magical Realism}

Rushdie characteristically employs elements of magical realism in Quichotte, as is evident from the numerous instances strewn across the novel. Eva Aldea discusses about "the specific political potential of magical realism" and notes how "the focus has shifted from magical realism's fusing of the genres of the real and the surreal as a 'strategy of liberation' to the 'forms of diversity and multiplicity' that magical realism is seen to introduce into the text." (2011, p.57) A statue of Hans Christian Andersen gives advice to Quichotte, the television reporter communicates with him directly from within the screen, and his gun talks back to him; an Italian cricket talks to Sancho, who is also guided by the fabular Blue Fairy. Marguerite Alexander describes Rushdie's use of magical realism as the "magic realization of metaphor" where he "interprets a metaphor that is then enacted" in the novel.(Bowers, 2013, p.51) Rushdie makes use of the implicit metaphor of totalitarianism in Eugene Ionesco's absurd drama Rhinoceros (1959). When Quichotte and Sancho arrive at the town of Berenger, they witness the metamorphosis of people to mastodons or giant prehistoric elephants. The allusion to Ionesco is thinly veiled as the owner of the hotel is named Mr. Jonesco, and Berenger was the protagonist of Rhinoceros; the metafictional author later explains to his son about the significance of this episode:

“...the Absurd in general, that it both mocked and celebrated our inability to give life a truly coherent meaning, and of his mastodons in particular that maybe they said something about our growing dehumanisation, about how as a species we, or some of us, might be losing our moral compass and becoming, simultaneously, creatures out of a barbaric, prehuman, long-toothed past, and also monsters tormenting the human present." (Rushdie, 2019, p.362)

\section{Social Media}

The emergence of a Foucauldian 'panoptic' surveillance state and the role of social media in instantly shaping opinions and meting out verdicts in virtual kangaroo courts have endangered the privacy and stability of identities of people throughout the world. Lewandowsky, Ecker, \& Cook (2017) note that "the flexibility and fractionation offered by social media has allowed people to choose their favored 'echo chamber' in which most available information conforms to preexisting attitudes and biases." (p.7) Sister's observation that "Social media had no memory" speaks volumes about how the virtual world is insidiously encroaching upon our reality, replacing our memories and innermost desires with a digital ennui.(Rushdie, 2019, p.234)

\section{The Post-truth Political Culture}

In a New Yorker article "Truth, Lies, and Literature" (2018), Rushdie raises a questionpertinent to post-truth politics: 
"How to combat the political demagoguery that seeks to do what authoritarians have always wanted-to undermine the public's belief in evidence, and to say to their electorates, in effect, 'Believe nothing except me, for I am the truth'?"

and in the same article, he further elucidates the crucial role of the literary arts in constructing a reality as a counter-discourse which "can make people agree, in this time of radical disagreement, on the truths of the great constant, which is human nature."In Quichotte, Rushdie presents a thinly veiled satirical caricature of the American Presidentas a "chief executive who was obsessed by cable news, who pandered to a white supremacist base" (2019, p.46).

Rushdie draws attention to the harrowing problem of racism and xenophobia prevalent in America where immigrants of all races are subjected to various ordeals. Tabish Khair defines xenophobia as "theattempt to reduce the other to a stranger and/or to reduce the strangeness of the other in a bid to empower oneself on terms denied to the other." (2016, p.187) Quichotte and Sancho, and later Brother and his son are abused and threatened by racists and witness the killing of two Indian men at a restaurant. This incident is based on the case of two Indian software engineers who were shot to death in 2017 in Olathe, Kansas, and is indicative of "America's gundeath pandemic." (Lunn, 2019, p.2) Sancho is even beaten up for merely staring at three white men, whom he imagined to be wearing dog collars, a subtle signifier of their inhumanity. Rushdie goes on a tirade enumerating the nefarious incidents that took place in America and India:

"Black citizens were regularly killed by white policemen...,or arrested in hotel lobbies for the crime of making a phone call to their mothers, and children were murdered in schools because of a constitutional amendment that made it easy to murder children in schools...a man was lynched for the crime of having what they thought was beef in his kitchen." (Rushdie, 2019, p.54)

With the meteoric rise of far-right politicians around the world, communal animosity is increasing by the day as ultra-nationalists are inciting people to identify patriotism with religion and race. Humanity is losing faith in itself as the hegemonic political ideologies, verging on neofascism, are stripping people of their identities. Quichotte expresses this anguish and despair when he says "all around me America - andnot only America, the whole human race! - yes, even our India! - wasalso losing its reason, its capacity for ethics, its goodness, its soul." (Rushdie, 2019, p.381)

\section{Conclusion}

Rushdie percipiently diagnoses the post-truth predicament as "the attack on truth by lies...the pollution of real by the unreal, of fact by fiction...the erosion and devaluation of the empirical intellect and its replacement by confirmations of previously held prejudices" (Rushdie, 2019, p.231). The predicament of the human condition in the contemporary post-truth culture is perhaps best expressed by Sancho, when he observes that "conscience isn't a major requirement in human affairs. Ruthlessness, narcissism, dishonesty, greed, bigotry, violence, yes." (Rushdie, 2019, p.342) In a world which has lost touch with reality, "Maybe this was the human condition, to live inside fictions created by untruths or the withholding of actual truths. Maybe human life was truly fictional in this sense, that those who lived it didn't understand it was real."(Rushdie, 2019, p. 175)Rushdie's Quichotteadroitly foregrounds the pervasive social and political issues endemic to the "Age-of-Anything-Can-Happen", and perhaps, it is high time that the inhabitants of this posttruth world focus their attention towards these aggravating afflictions. 


\section{References}

Aldea, E. (2011). Magical Realism and Deleuze: The indiscernibility of difference in postcolonial literature. Bloomsbury.

Badiou, A. (2012). Metapolitics. Verso Trade.

Badiou, A. (2014). Infinite Thought: Truth and the Return to Philosophy (O. Feltham, \& J. Clemens, Trans.). Bloomsbury.

Baudrillard, J. (1996). The Perfect Crime. Verso.

Bowell, T. (2018). Changing the world one premise at a time: Argument, imagination and post-truth. PostTruth, Fake News, 169-185. https://doi.org/10.1007/978-981-10-8013-5_15

Bowers, M. A. (2013). Magic(al) Realism. Routledge.

Caputo, J. D. (2013). Truth: Philosophy in transit. Penguin UK.

Colebrook, C. (2015). Gilles Deleuze. Routledge.

Dobson, A. (2016). Environmental Politics: A very short introduction. Oxford University Press.

Edgar, A. (2006).Habermas: The Key Concepts. Routledge.

Foucault, M., Faubion, J. D., \& Hurley, R. (2000). Power. Penguin.

Hannan, J. (2018). Trolling ourselves to death? Social media and post-truth politics.EuropeanJournal of Communication, 33(2), 214-226.https://doi.org/10.1177/0267323118760323

Harari, Y. N. (2018). 21 Lessons for the 21st Century. Jonathan Cape.

Hornby, A. S. (Ed.). (2020). Oxford Advanced Learner's Dictionary (1oth ed.).

Kalpokas, I. (2019). A Political Theory of Post-Truth. Palgrave Pivot.

Kester, K. (2018). Postmodernism in post-truth times. What Comes After Postmodernism in Educational Theory?, 34-35. https://doi.org/10.4324/9781003021032-14

Khair, T. (2016). The New Xenophobia. Oxford University Press.

Levine, D. P. (2017). Psychoanalysis, Society, and the Inner world: Embedded Meaning in Politics and Social Conflict. Taylor \& Francis.

Lewandowsky, S., Ecker, U.K., \& Cook, J. (2017). Beyond misinformation: Understanding and coping with the "post-truth" era. Journal of Applied Research in Memory and Cognition, 6(4), 353369. https://doi.org/10.1016/j.jarmac.2017.07.008

Lundborg, T. (2016). The virtualization of security: Philosophies of capture and resistance in Baudrillard, Agamben and Deleuze. Security Dialogue, 47(3), 255-270. doi:10.1177/o967010615625474

Lunn, D. (2019, September 6). Salman Rushdie on his latest novel, 'Quichotte'. The Hindu. https://www.thehindu.com/books/books-authors/salman-rushdie-on-his-latest-novelquichotte/article29352774.ece

McIntyre, L. (2018). Post-Truth. MIT Press.

National Institute on Drug Abuse. (2019, January 22). Opioid Overdose Crisis. Retrieved from https://www.drugabuse.gov/drugs-abuse/opioids/opioid-overdose-crisis\#one 
9 | Salman Rushdie's Quichotte and the Post-truth Condition

Orwell, G. (2017). Orwell On Truth. Random House.

Prozorov, S. (2018). Why is there truth? Foucault in the age of post-truth politics.Constellations, 26(1), 1830. doi:10.1111/1467-8675.12396

Quichotte book review: Salman Rushdie struggles to bring the sprawling satire to life. (2019, September 18). Retrieved from https://www.firstpost.com/living/quichotte-book-review-salman-rushdiestruggles-to-bring-the-sprawling-satire-to-life-7335851.html

Quichotte, by Salman Rushdie.

(n.d.). https://www.booklistonline.com/Quichotte/pid=9721813?AspxAutoDetectCookieSupport=1

Rancière, J. (2013). The Politics of Aesthetics. Bloomsbury Publishing.

Richmond, J. C., \&Porpora, D. V. (2019). Entertainment Politics as a Modernist Project in a Baudrillard World. Communication Theory. doi:10.1093/ct/qtyo36

Rushdie, S. (2010). Imaginary Homelands: Essays and Criticism 1981-1991. Vintage.

Rushdie, S. (2018, May 31). Salman rushdie on truth, lies, and literature. The New Yorker. https://www.newyorker.com/culture/cultural-comment/truth-lies-and-literature

Rushdie, S. (2019). Quichotte. Penguin Random House.

Salman Rushdie's Fantastical American Quest Novel. (n.d.). Retrieved from https://www.newyorker.com/podcast/political-scene/salman-rushdie-fantastical-american-questnovel

Simms, K. (2003). Paul Ricoeur. Routledge.

"The challenge of the post-truth era." (2018). Nature Cell Biology, 2o(11), 1231-1231. doi:10.1038/s41556-0180231-Z

Atri Majumder is currently pursuing his doctoral studies at the Department of Management, Humanities and Social Sciences, NIT Agartala. His poetry collection Visible Infinity was published by Writers Workshop in 2014. His areas of interest are contemporary politics, psychoanalytic criticism, and the works of Salman Rushdie.

Dr.GyanabatiKhuraijam is working as Assistant Professor (English) in the Department of Management, Humanities \& Social Sciences at National Institute of Technology, Agartala. She obtained her Ph.D from Manipur University. Her areas of interests are Commonwealth Literature, Indian Writing in English, Gender Studies, Postcolonial Studies, Communication, etc. Her research articles have been published in many international journals of repute. She has also authored two books. 